\title{
KAJIAN EFEKTIVITAS SISTEM INFORMASI JASA PENGIRIMAN BARANG BERDASARKAN KERAGAMAN JENIS KELAMIN, PENDIDIKAN DAN UMUR PENGGUNANYA
}

\author{
Fitriana Destiawati \\ Program Studi Teknik Informatika, Universitas Indraprasta PGRI \\ Email: honeyzone86@gmail.com
}

\begin{abstract}
Abstrak
Sebuah sistem adalah sekelompok elemen yang berkaitan erat satu sama lain, yang berfungsi bersama-sama untuk dapat direpresentasikan berdasarkan pada kualitas sistem, kualitas informasi, kualitas pelayanan, niat untuk menggunakan, kepuasan pengguna, dan keuntungan bersih. Untuk melihat hubungan antara variabel dalam model pendekatan ini akan diuji dengan menggunakan Structural Equation Modelling (SEM) dengan tes berdasarkan keragaman jenis kelamin, pendidikan dan usia pengguna. Berdasarkan hasil uji signifikan, ada beberapa variabel yang tidak signifikan. Oleh karena itu dapat disimpulkan bahwa Sistem Informasi mencapai tujuan tertentu. Sementara sistem informasi adalah komponen terkait satu sama lain bekerja sama untuk mengumpulkan, memproses, menyimpan dan menyebarkan informasi untuk mendukung pengambilan keputusan, koordinasi, pengendalian, menganalisis, dan memvisualisasikan dalam organisasi. Berdasarkan model pendekatan DeLone dan McLean untuk keberhasilan sistem informasi jasa pengiriman barang belum efektif.
\end{abstract}

Kata Kunci: Information Systems, DeLone and McLean, Structural Equation Modelling.

\section{Pendahuluan}

Seiring dengan perkembangan teknologi yang semakin maju, banyak perusahaan yang berusaha membuat atau mendesain suatu sistem informasi yang diharapkan mampu berjalan efektif sehingga memberikan manfaat positif terhadap kinerja karyawan pada perusahaan tersebut. Untuk meningkatkan efisiensi waktu dan tenaga para karyawannya, pada tahun 2009 CV. Viradi Global Pratama mencoba menggunakan sebuah aplikasi sistem informasi jasa pengiriman barang yang berfungsi untuk mendata semua pemesanan jasa pengiriman barang pada perusahaan tersebut.

Setelah melihat penerapan dan penggunaan sistem informasi jasa pengiriman barang yang ada saat ini, ternyata masih ditemukan beberapa masalah misalnya penyimpanan data masih kurang efisien, pengolahan data juga masih dirasakan lambat khususnya ketika menerima atau mengirim data, serta kurangnya minat penggunaan sistem.

Melihat masalah-masalah yang ada maka dalam penelitian ini akan digunakan metode pendekatan DeLone McLean untuk mengukur kesuksesan dan keefektifan Sistem Informasi Jasa Pengiriman Barang pada CV. Viradi Global Pratama yang akan diuji dengan menggunakan metode Structural Equation Modeling (SEM).

\section{Tinjauan Pustaka}

Menurut (Sutabri, 2004) Suatu sistem adalah sekelompok unsur yang erat hubungannya satu dengan yang lain, yang berfunsi bersama-sama untuk mencapai tujuan tertentu. Sedangkan informasi dapat didefinisikan sebagai hasil dari pengolahan data dalam suatu bentuk yang lebih berguna dan lebih berarti bagi penerimanya yang menggambarkan suatu kejadian (event) yang nyata (fact) yang digunakan untuk pengambilan keputusan(Tia Septiani, 2013).

Sehingga sistem Informasi adalah komponen-komponen yang terkait satu sama lainnya yang bekerjasama untuk mengumpulkan, memproses, menyimpan dan menyebarkan informasi guna mendukung pengambilan keputusan, koordinasi, pengendalian, analisis, dan memvisualisasikan di dalam organisasi. 
Menurut (Widowati, 2004), sistem yang efektif didefinisikan sebagai suatu sistem yang dapat memberikan nilai tambah kepada perusahaan. Oleh karena itu, sistem yang efektif harus dapat memberikan pengaruh yang positif kepada perilaku pengguna.

Berdasarkan teori efektifitas dan teori sistem yang dijelaskan sebelumnya maka dapat disimpulkan bahwa sistem yang efektif didefinisikan sebagai suatu sistem yang dapat memberikan nilai tambah kepada perusahaan. Oleh karena itu, sistem yang efektif harus dapat memberikan pengaruh yang positif kepada perilaku user. Jasa merupakan suatu kegiatan yang ditawarkan oleh suatu pihak kepada pihak lainnya. Berdasarkan pengertian dari jasa itu sendiri, maka dapat ditarik kesimpulan bahwa jasa pengiriman barang merupakan suatu kegiatan penawaran untuk mengirimkan barang dari satu pihak ke pihak yang lain.

Berbagai variabel dapat mempengaruhi efektivitas sistem informasi. Salah satu model pengukuran keberhasilan sistem informasi dikemukakan (DeLone \& Mclean, 2003), yang dikenal dengan D\&M IS Success.

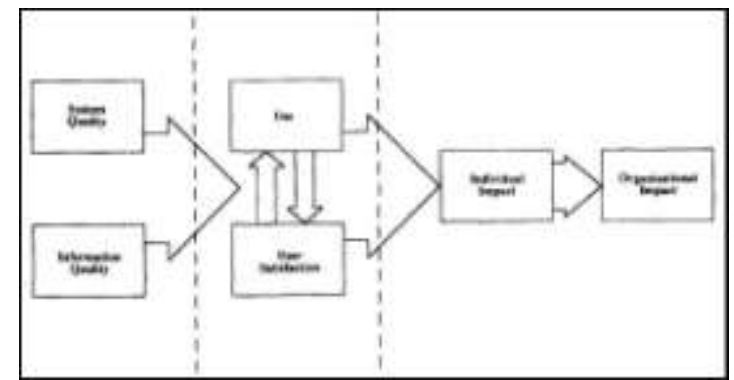

Gambar 1. Model D\&M IS Success (Delone \& Mclean, 2004).

(Delone; McLean, 2003) Keberhasilan sistem informasi terdiri dari enam variabel, yaitu System Quality, Information Quality, System Use, User Satisfaction, Individual Impact, dan Organizational Impact. Sementara dalam penelitian DeLone dan McLean yang terbaru, model tersebut mengalami perubahan. Model ini dikembangkan untuk mengevaluasi D\&M IS Success Model dengan menambahkan variabel service quality dan net benefit.

Pada model yang baru ini (Delone \& Mclean, 2004) menambahkan kualitas pelayanan sebagai dimensi yang tidak kalah penting dengan kualitas sistem dan kualitas informasi. Sehingga pada model DeLone dan McLean yang baru ini variabel yang digunakan adalah System Quality, Information Quality, Service Quality, Intention to Use, User Satisfaction dan Net Benefit.

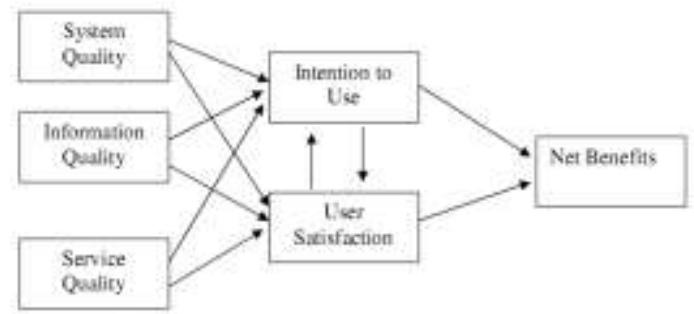

Gambar 2. The Update D\&M IS Success Model (Delone \& Mclean, 2004).

1. System Quality, yaitu tingkat pentingnya informasi, relevansi, kegunaan, informativeness, kegunaan, kepahaman, dapat dibaca, kejelasan, format, tampilan, isi, akurasi, presisi, conciseness, kehandalan, kekinian, timeliness, keunikan, comparability, jumlah, bebas bias.

2. Information Quality, yaitu akurasi data, kekinian data, isi basisdata, kemudahan penggunaan, kemudahan dipelajari, kenyamanan akses, faktor manusia, integrasi 
system, realisasi kebutuhan pengguna, kegunaan fungsi dan fitur system, akurasi system, keluwesan system, keandalan system, system sophistication, penggunaan sumber daya, waktu respon, turnaround time.

3. Service Quality, yaitu tangible, kehandalan, responsifitas, kepastian layanan, dan empati.

4. Intention to Use, yaitu yaitu minat memakai (intention to use). Minat memakai adalah suatu sikap (attitude). Sedang pemakaian (use) adalah suatu perilaku (behaviour).

5. User Satisfaction, kepuasan informasi yang dibutuhkan dan yang diterima, kesenangan, kepuasan atas software, dan kepuasan mengambil keputusan.

6. Net Benefits, pemahaman informasi, pembelajaran, akurasi interpretasi, kesadaran informasi, information recall, identifikasi masalah, peningkatan produktifitas individual, perubahan keputusan, penyebab tindakan manajemen, pengaruh individual, kinerja pekerjaan, kualitas rencana, nilai personal atas SI, kemauan membayar informasi.

Kerangka pemikiran pada penulisan ini adalah mengacu pada The Update DeLone \& McLean IS Success Model (Bossen, Jensen, \& Udsen, 2013) dalam menentukan tingkat efektifitas penggunaan Sistem Informasi Jasa Pengiriman Barang dengan melihat melihat bagaimana penerapan teori model DeLone \& McLean pada Sistem Informasi Jasa Pengiriman Barang yang ada pada CV. Viradi Global Pratama Berdasarkan kerangka konsep pengaruh antar variabel, maka disusunlah hipotesis sebagai berikut :

$\mathrm{H1}$ : Diduga kualitas informasi (KI) berpengaruh positif terhadap kepuasan pengguna (KP)

H2: Diduga kualitas sistem (KS) berpengaruh positif terhadap kepuasan pengguna (KP).

H3: Diduga kualitas layanan (KL) berpengaruh positif terhadap kepuasan pengguna (KP).

$\mathrm{H} 4$ : Diduga kepuasan pengguna sistem (KP) dapat menghasilkan manfaat bersih bagi perusahaan $(\mathrm{MB})$.

\section{Metodologi Penelitian}

Dalam menguji hipotesis peneliti menggunakan metode statistic multivariate Structural Equation Model (SEM) dengan tujuan untuk memperoleh model yang Plausible atau fit (sesuai cocok) dengan masalah yang sedang dikaji pada penelitian ini. Selain itu metode analisa menggunakan SEM memiliki tujuan juga untuk mengetahui hubungan kausal antar variable dependen atau independen pada model yang dibangun.

Adapun langkah-langkah dari metode analisa dengan menggunakan teknik analisa Structural Equation Model (SEM) (Hair, Ringle, \& Sarstedt, 2011) adalah sebagai berikut:

1. Pengembangan Model Berbasis Teori

Tujuan pengembangan model berbasis teori ini adalah untuk mengembangkan sebuah model yang mempunyai pembenaran secara teoritis yang kuat, untuk mendukung upaya analisis terhadap suatu masalah yang menjadi objek penelitian. Pada penilitian ini terdapat 3 konstruk eksogen, yaitu kualitas sistem (KS), kualitas informasi (KI), dan kualitas layanan $(\mathrm{KL})$. Selain itu juga terdapat 3 konstruk endogen yaitu kepuasan pengguna (KP), pengguna (P) dan manfaat bersih (MB).

2. Uji Validitas dan Reliabilitas

Uji validitas digunakan untuk menguji keakuratan suatu indikator sehingga dapat mewakili suatu variabel laten. Sedangkan uji reliabilitas merupakan suatu ukuran konsistensi internal dari indikator-indikator suatu variable bentukan yang menunjukan derajat setiap indikator sebagai konstruktor variable bentukan.

3. Uji Asumsi Model

Tindakan yang dilakukan adalah mengevaluasi apakah data tersebut telah memenuhi asumsi-asumsi SEM. Asumsi-asumsi yang harus dipenuhi adalah :

a. Ukuran Sampel, ukuran sampel yang digunakan berkisar antara 100-200. 
b. Normalitas, dengan melihat nilai critical ratio skewness dan critical ratio curtosis value yang berada pada -2.58 sampai 2.58 dengan tingkat signifikasi 0.01 maka data dianggap normal.

c. Outliers, Deteksi terhadap multivariat outlier dilakukan dengan memperhatikan nilai mahalonobis distance table. Jika nilai p1 dan p2 $<0.05$ maka data dianggap outlier.

d. Multikolinearitas dan Singularitas, Multikolinearitas dan Singularitas dapat di deteksi dari determinan matrik kovarians, jika determinan dari matrik kovarians sangat besar atau jauh dari angka nol maka data tersebut valid.

4. Uji Kesesuaian Model

Uji ini adalah uji model secara menyeluruh yang ditujukan utnuk mengukur kesesuaian antara matriks varians kovarians sampel (data observasi) dengan matrik varian kovarians berdasarkan model yang diajukan. Dengan kata lain, uji ini digunakan untuk menyatakan model fit atau tidak. Jika model dianggap tidak fit maka penelitian selanjutnya harus dilakukan melakukan path diagram. Tujuannya adalah untuk memudahkan dalam melihat hubungan kausalitas yang ingin diuji.

5. Uji Signifikansi

Setelah model penelitian menggunakan diagram jalur terbentuk, kemudian dilakukan pengujian signifikasi. Jika terdapat koefisien regresi yang bernilai negatif atau yang tidak signifikan maka dihapus. Suatu nilai $\mathrm{p}$ dianggap signifikan apabila nilai $\mathrm{p}$ tersebut memiliki angka dibawah 0.05 .

6. Analisa Sub-Grup Model Moderating

Analisa sub-grup model moderating merupakan suatu model analisa dengan memisahkan variable moderating menjadi dua kelompok. Umumnya berdasarkan nilai diatas rata-rata (tinggi) atau dibawah rata-rata (rendah), kemudian dilakukan estimasi dua model dengan kondisi variable moderating tinggi dan rendah. Setelah itu membandingkan hasil koefisien parameter kedua model untuk melihat ada tidaknya pegaruh moderasi dalam model.

7. Analisa Efektivitas

Keefektifan sebuah sistem dapat dilihat apabila variabel-variabel yang ada pada model untuk pengujian sistem informasi tersebut memiliki hubungan yang signifikan.

Jika dalam sebuah model terdapat minimal satu variabel yang memiliki hubungan yang tidak signifikan maka model untuk pengujian sistem informasi tersebut dianggap tidak efektif.

\section{Hasil dan Pembahasan}

Responden yang ada pada penelitian ini adalah karyawan pada CV. Viradi Global Pratama dengan jumlah responden sebanyak 120 responden yang diklasifikasi berdasarkan posisi tempat bekerja, jenis kelamin, usia, pendidikan terakhir, dan lama menggunakan komputer.

\section{Analisa Statistik Deskriptif}

Dilihat hasil sum dari statistic deskriptif memiliki nilai minimal 348 dan nilai maksimum 594.5. Standar deviation memiliki nilai minimal 0.68 dan nilai maksimal 1.15. Sedangkan nilai c.r pada skewness dan kurtosis dalam kisaran nilai yang direkomendasikan yaitu -2.58 sampai 2.58.

\section{Pengujian Model Berbasis Teori}

Pengujian model berbasis teori dilakukan dengan menggunakan software AMOS (IBM SPSS Amos, 2012). Setelah melakukan pengumpulan data dengan menggunakan kuesioner.

Pada penelitian ini Sistem Informasi Jasa Pengiriman Barang yang terdapat pada CV. Viradi Global Pratama bersifat monoton sehingga responden atau pengguna wajib menggunakan sistem informasi tersebut dalam kegiatan pengiriman barang.

Oleh karena itu, variabel Penggunaan (P) tidak berpengaruh terhadap model tersebut. Sehingga untuk pengujian model selanjutnya digunakan model sebagai berikut: 


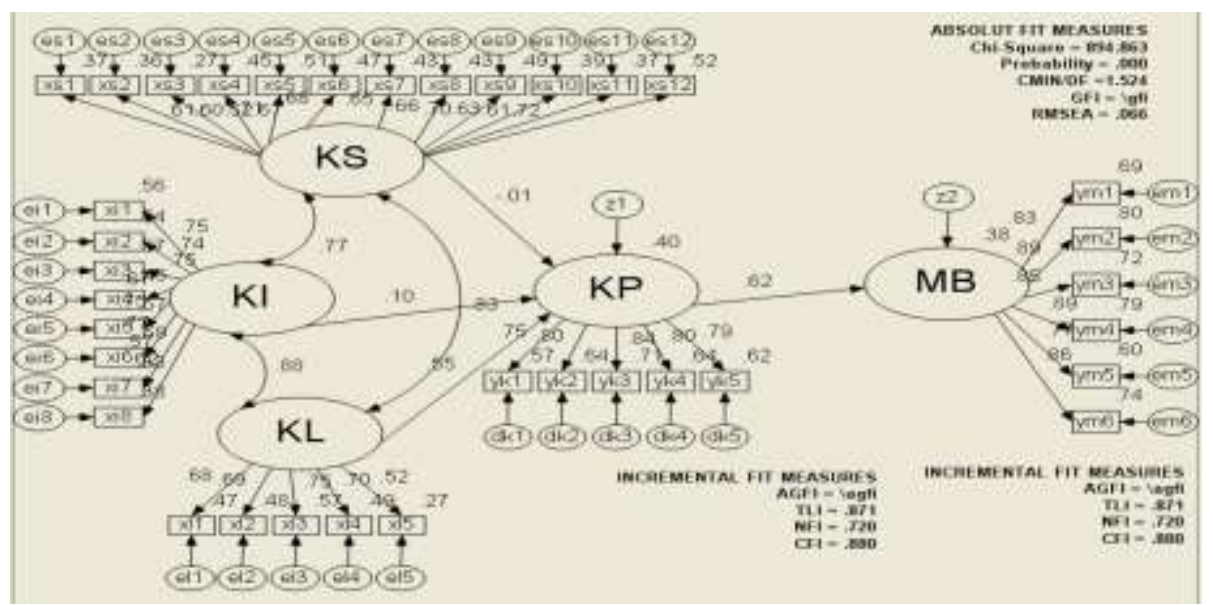

Gambar 3. Model Awal Penelitian

\section{Uji Validitas}

Pengujian validitas mengukur sampai seberapa jauh ukuran indikator mampu merefleksikan konstruk laten teoritisnya berdasarkan nilai loading factor-nya.

Variabel kualitas sistem (KS), kualitas Informasi (KI), kepuasan penggunaan (KP), dan manfaat bersih (MB) dinyatakan valid karena semua konstruk yang ada pada variabel tersebut memiliki nilai estimasi diatas 0.5 . Sedangkan untuk variabel kualitas layanan (KL) dinyatakan tidak valid karena pada variabel tersebut terdapat konstruk yang tidak valid atau memiliki nilai dibawah 0.5 .

\section{Uji Reliabilitas}

Semua konstruk variabel laten KS, KI, KL, KP dan MB memenuhi syarat cutt-of value untuk construct reliability minimal 0.70 . Sedangkan nilai variance extracted untuk konstruk variabel laten KL, KP, dan MB memenuhi batas nilai variance extracted yaitu berada diatas 0.50 . Akan tetapi untuk variabel laten KS dan KI memiliki nilai variance extracted dibawah 0.50. Dengan demikian dapat dikatakan bahwa masing-masing variabel memiliki realibilitas yang baik.

Tabel 1. Uji Realiabilitas

\begin{tabular}{ccc}
\hline Variabel Laten & Construct Reliability & Variance Extracted \\
\hline KS & 0,896 & 0,420 \\
KI & 0,888 & 0,499 \\
KL & 0,807 & 0,514 \\
KP & 0,898 & 0,637 \\
MB & 0,939 & 0,720 \\
\hline
\end{tabular}

\section{Uji Asumsi}

\section{Uji Normalitas}

Uji normalitas dapat dilihat secara univariate maupun multivariate. Pada tabel 2 nilai yang berada pada kolom c.r. berada diluar kisaran -2.58 sampai 2.58 (Signifikans pada 1\%). Secara multivariate nilai c.r yaitu 5.055 yang nilainya jauh diatas 2.58. Sehingga dapat disimpulkan bahwa data berdistribusi tidak normal. 
Tabel 2. Uji Normalitas

\begin{tabular}{ccccccc}
\hline Variable & Min & max & skew & c.r & kurtosis & C, \\
\hline x15 & 2.000 & 6.000 & .704 & 2.957 & .179 & .376 \\
ym6 & 2.000 & 6.000 & -.712 & -2.992 & -.893 & -1.877 \\
ym5 & 3.000 & 6.000 & -.205 & -.863 & -1.414 & -2.971 \\
ym4 & 2.000 & 6.000 & -.410 & -1.723 & -1.159 & -2.435 \\
ym3 & 3.000 & 6.000 & -.310 & -1.301 & -1.383 & -2.906 \\
ym2 & 3.000 & 6.000 & -.250 & -1.052 & -1.425 & -2.995 \\
ym1 & 2.000 & 6.000 & -.277 & -1.166 & -1.236 & -2.597 \\
yk5 & 2.000 & 6.000 & .485 & 2.039 & .095 & .200 \\
yk4 & 2.000 & 6.000 & .257 & 1.078 & -.563 & -1.184 \\
yk1 & 2.000 & 6.000 & .306 & 1.288 & -.346 & -.728 \\
yk2 & 2.000 & 6.000 & .037 & .155 & -.529 & -1.112 \\
yk3 & 2.000 & 6.000 & .430 & 1.807 & -.219 & -.459 \\
x11 & 2.000 & 6.000 & -.011 & -.045 & -.242 & -.509 \\
x12 & 2.000 & 5.500 & .350 & 1.472 & -.491 & -1.032 \\
x13 & 2.000 & 5.500 & .173 & .726 & -.226 & -.475 \\
x14 & 2.000 & 5.500 & .336 & 1.413 & -.369 & -.776 \\
xi1 & 2.000 & 5.000 & .788 & 3.313 & -.010 & -.020 \\
xi2 & 2.000 & 5.500 & .468 & 1.966 & -.547 & -1.151 \\
xi3 & 2.000 & 5.500 & .667 & 2.805 & -.214 & -.450 \\
xi4 & 2.000 & 5.500 & .635 & 2.667 & -.056 & -.117 \\
xi5 & 2.000 & 5.500 & .881 & 3.704 & .925 & 1.944 \\
xi6 & 2.000 & 4.500 & .562 & 2.364 & -.298 & -.626 \\
xi7 & 2.000 & 5.500 & 1.029 & 4.325 & .852 & 1.791 \\
xi8 & 2.000 & 5.500 & .586 & 2.465 & -.395 & -.830 \\
Multivariate & & & & & 34.692 & 5.055 \\
\hline
\end{tabular}

2. Uji Outlier

Sebuah data termasuk outlier jika mempunyai angka $p 1$ dan $p 2$ yang kurang dari 0,05.

Tabel 3. Uji Outlier

\begin{tabular}{|c|c|c|c|c|c|c|c|c|}
\hline $\begin{array}{c}\text { Observation } \\
\text { Number }\end{array}$ & P1 & P2 & $\begin{array}{c}\text { Observation } \\
\text { Number }\end{array}$ & P1 & P2 & $\begin{array}{c}\text { Observation } \\
\text { Number }\end{array}$ & P1 & P2 \\
\hline 88 & .000 & .003 & 53 & .227 & .039 & 82 & .680 & .984 \\
\hline 15 & .000 & .000 & 24 & .253 & .099 & 29 & .683 & .979 \\
\hline 94 & .000 & .000 & 27 & .257 & .086 & 61 & .704 & .991 \\
\hline 109 & .001 & .000 & 96 & .292 & .241 & 34 & .720 & .994 \\
\hline 108 & .003 & .000 & 46 & .299 & .230 & 90 & .720 & .991 \\
\hline 80 & .004 & .000 & 11 & .339 & .514 & 56 & .723 & .987 \\
\hline 85 & .005 & .000 & 86 & .343 & .472 & 8 & .726 & .983 \\
\hline 92 & .014 & .000 & 91 & .359 & .538 & 105 & .736 & .986 \\
\hline 21 & .019 & .001 & 33 & .393 & .749 & 106 & .745 & .987 \\
\hline 5 & .019 & .000 & 104 & .410 & .808 & 14 & .751 & .986 \\
\hline 4 & .026 & .000 & 72 & .422 & .827 & 26 & .763 & .989 \\
\hline 6 & .029 & .000 & 20 & .426 & .805 & 116 & .796 & .999 \\
\hline 3 & .032 & .000 & 60 & .442 & .846 & 77 & .799 & .998 \\
\hline 48 & .035 & .000 & 87 & .457 & .877 & 12 & .800 & .997 \\
\hline 119 & .050 & .001 & 103 & .475 & .915 & 2 & .804 & .996 \\
\hline 69 & .075 & .017 & 22 & .476 & .885 & 32 & .811 & 999 \\
\hline 52 & .075 & .008 & 70 & .478 & .857 & 107 & .834 & .999 \\
\hline 39 & .077 & .005 & 59 & .485 & .850 & 114 & .842 & 1.000 \\
\hline 95 & .078 & .002 & 89 & .490 & .831 & 115 & .854 & 1.000 \\
\hline 97 & .081 & .002 & 111 & .491 & .787 & 36 & .867 & 1.000 \\
\hline 23 & .082 & .001 & 117 & .522 & .905 & 110 & .867 & 1.000 \\
\hline 73 & .083 & .000 & 118 & .525 & .884 & 101 & .878 & 1.000 \\
\hline 102 & .095 & .001 & 113 & .527 & .854 & 78 & .920 & 1.000 \\
\hline 16 & .098 & .001 & 38 & .529 & .817 & 25 & .920 & 1.000 \\
\hline 9 & .099 & .000 & 10 & .535 & .808 & 18 & .924 & 1.000 \\
\hline 51 & .100 & .000 & 120 & .539 & .779 & 1 & .933 & 1.000 \\
\hline
\end{tabular}


Jurnal String Vol.1 No.2 Tahun 2016

\begin{tabular}{ccccccccc}
\hline 45 & .125 & .002 & 62 & .547 & .777 & 99 & .937 & 1.000 \\
64 & .166 & .036 & 63 & .575 & .886 & 37 & .938 & 1.000 \\
112 & .192 & .105 & 31 & .581 & .875 & 50 & .941 & 1.000 \\
19 & .196 & .087 & 44 & .609 & .946 & 81 & .946 & 1.000 \\
41 & .203 & .086 & 66 & .621 & .953 & & & \\
17 & .208 & .075 & 13 & .632 & .961 & & & \\
98 & .211 & .058 & 68 & .656 & .983 & & & \\
75 & .220 & .061 & 67 & .659 & .987 & & & \\
35 & .224 & .052 & 55 & .674 & .986 & & & \\
\hline
\end{tabular}

Berdasarkan pada output dari tabel 3 tersebut dapat dilihat bahwa data pada responden 88 , $15,94,109,108,80,85,92,21,5,4,6,3$, dan 48 memiliki nilai p1 dan p2 dibawah 0.05 , maka dapat dikatan bahwa data tersebut dianggap outlier. Dengan demikian data-data tersebut harus dihapus dari proses analisis. Sehingga jumlah responden dari 120 menjadi 106 responden.

\section{Uji Singularitas}

Untuk uji singularitas dapat dilihat berdasarkan nilai determinant of sample covariance matrix $=.000$. Sehingga berdasarkan data yang ada, dapat dianggap bahwa tidak ada masalah multikoliniearitas dan singularitas pada data yang dianalisis.

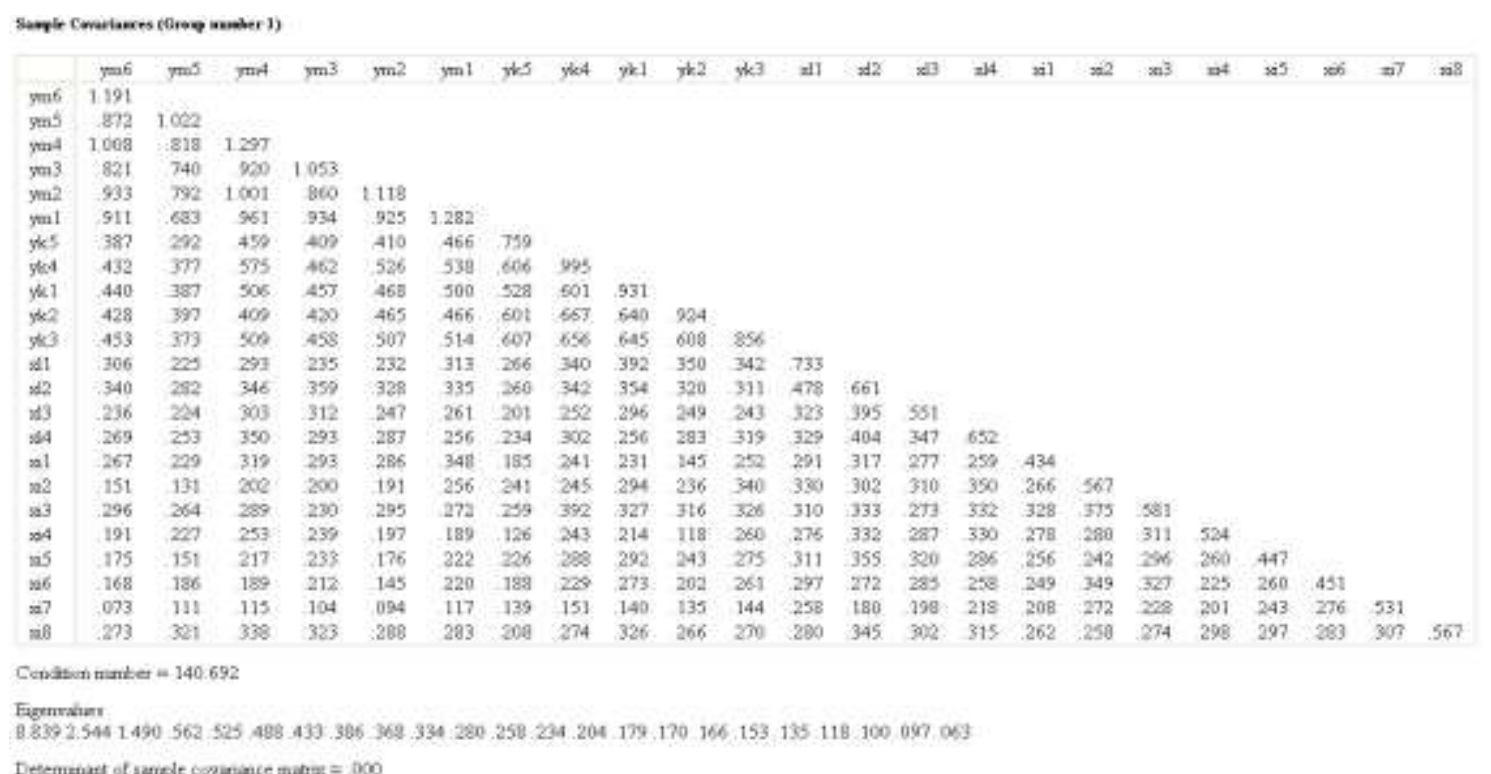

Gambar 4. Uji Singularitas

\section{Uji Kesesuaian Model}

Uji kesesuaian model dilakukan dengan melihat nilai probability. Berdasarkan hasil output dari model penelitian yang ada, maka nilai probability-nya adalah 0.000 atau berada dibawah 0.05 . 


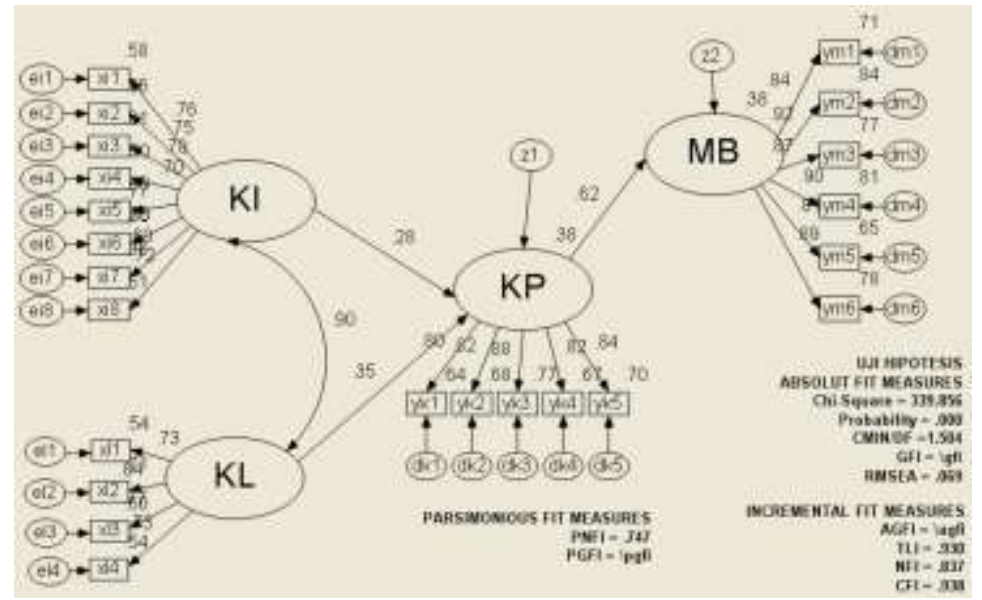

Gambar 5. Uji Kesesuaian Model

Dengan demikian model penelitian dianggap tidak fit dan harus dilakukan pengujian menggunakan model jalur atau path diagram.

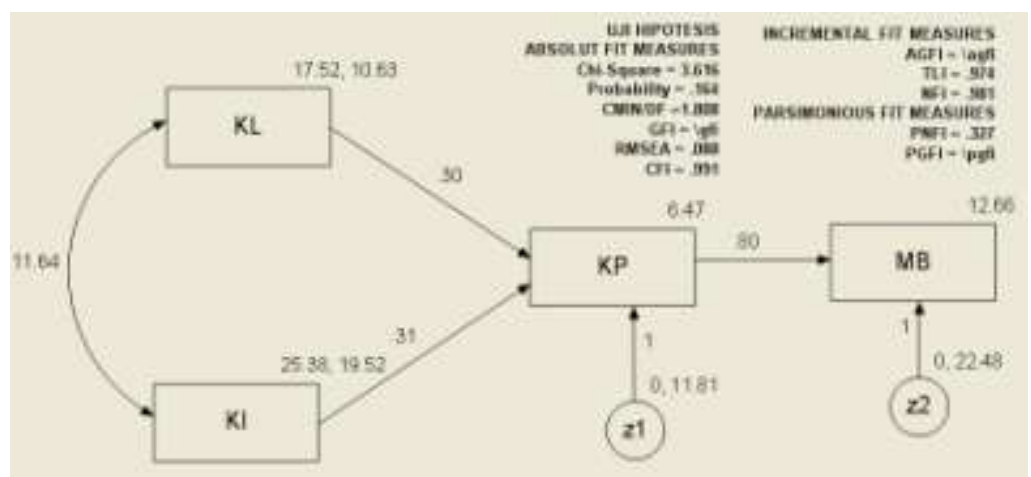

Gambar 6. Model Jalur atau Path Diagram

\section{Uji Signifikansi}

Berdasarkan hasil pengujian signifikansi maka didapatkan nilai dibawah 0.05 yaitu terdapat pada jalur dari variabel KI menuju KP dengan nilai 0.017. Dengan demikian jalur dari variabel KI menuju KP dianggap signifikan.

Sedangkan untuk jalur dari variabel KL menuju KP memiliki nilai 0.085 atau dengan kata lain jalur dari variabel KL menuju KP dianggap tidak signifikan dan harus dihapus dari model analisis.

\begin{tabular}{lc}
\multicolumn{2}{l}{ Tabel 4. } \\
\hline Jalur & Nignifikansi \\
\hline $\mathrm{KP} \leftarrow \mathrm{KI}$ & 0.017 \\
$\mathrm{KP} \leftarrow \mathrm{KL}$ & 0.085 \\
$\mathrm{MB} \leftarrow \mathrm{KP}$ & 0.050 \\
\hline
\end{tabular}

\section{Model Akhir Penelitian}

Setelah dilakukan uji signifikansi maka terdapat jalur yang dihapus yaitu jalur dari variabel KI menuju KP. 


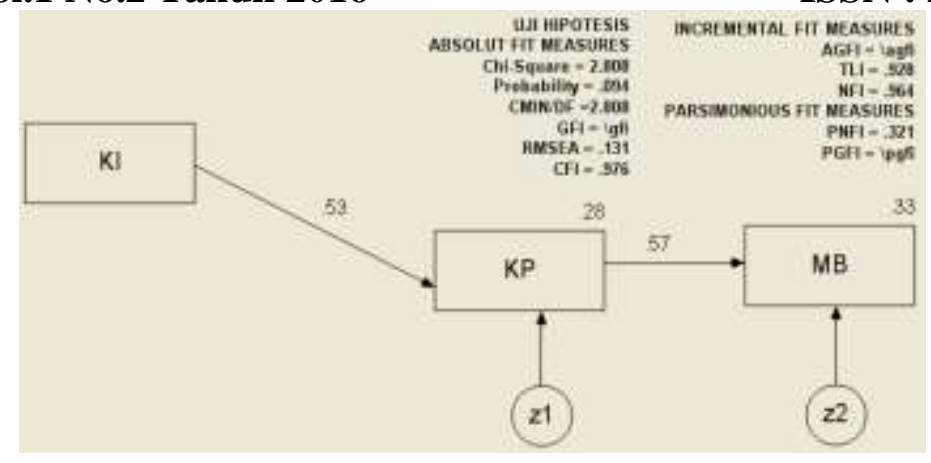

Gambar 7. Model Akhir Penelitian dalam Bentuk Path Diagram

Dari gambar 7 diketahui nilai koefisien standardized untuk pengaruh kualitas informasi terhadap kepuasan penggunaan sebesar 0.53. Nilai koefisien standardized pengaruh kepuasan penggunaan terhadap manfaat bersih sebesar 0.57. Berdasarkan hasil uji signifikan tersebut maka didapatkan model analisis akhir sebagai berikut :

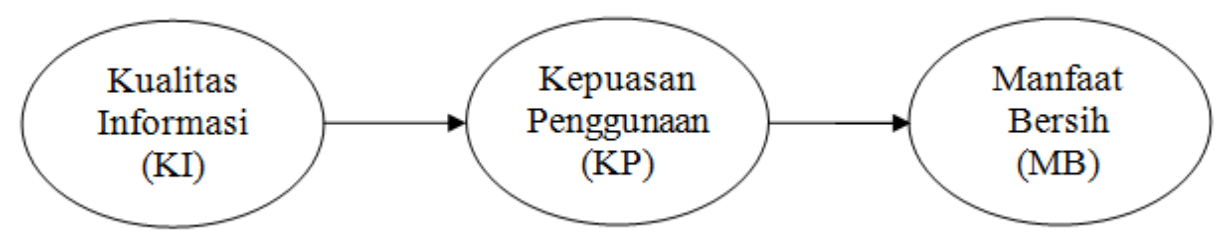

\section{Gambar 8. Model Akhir Penelitian}

\section{Analisa Efektivitas}

Berdasarkan model akhir penelitian bahwa terdapat variabel yang dianggap tidak signifikan yaitu variabel kualitas layanan (KL) yang memiliki nilai diatas 0.05 yaitu 0.085 . Dengan demikian berdasarkan hasil tersebut maka dapat disimpulkan bahwa sistem informasi jasa pengiriman barang yang ada pada CV. Viradi Global Pratama masih belum efektif

\section{Analisa Sub-Grup Model Moderating}

Jika dilihat berdasarkan analisa sub-grup model moderating untuk keragaman jenis kelamin, maka pengguna wanita memiliki tingkat kepuasan penggunaan sistem yang dipengaruhi oleh kualitas informasi, lebih tinggi dibandingkan dengan pengguna pria. Hal ini dimungkinkan karena tingkat interaksi pengguna wanita terhadap sistem lebih tinggi dibandingkan pengguna pria.

Sedangkan untuk kriteria pendidikan pengguna dengan pendidikan terakhir SLTA sampai D3 dan kategori pengguna dengan pendidikan terakhir S1 sampai S3 memiliki tingkat kepuasan yang sama dalam menggunakan sistem. Hal ini dipengaruhi oleh kualitas informasi yang diterima oleh pengguna dari kedua kategori tersebut.

Untuk kriteria umur penggunanya pengguna dengan usia dibawah 30 tahun dan pengguna dengan usia diatas 30 tahun memiliki tingkat kepuasan yang sama terhadap penggunaan sistem informasi jasa pengiriman barang.

\section{Simpulan dan Saran}

\section{Simpulan}

Berdasarkan hasil penelitian ini maka didapat beberapa kesimpulan sebagai berikut:

1. Kualitas sistem. kualitas layanan, dan penggunaa tidak mempengaruhi efektivitas Sistem Informasi Jasa Pengiriman Barang. 
2. Sedangkan faktor yang mempengaruhi efektivitas pemanfaatan Sistem Informasi Jasa Pengiriman Barang adalah kualitas informasi dan kepuasan pengguna.

3. Model kesuksesan sistem informasi DeLone and McLean tidak sepenuhnya terbukti secara empiris dalam kasus pemanfaatan Sistem Infromasi Jasa Pengiriman Barang pada CV. Viradi Global Pratama.

4. Makin tinggi kualitas informasi maka akan mempengaruhi terhadap kepuasan pengguna dan makin tinggi tingkat kepuasan pengguna, maka semakin meningkat pula manfaat yang didapatkan.

5. Sistem Informasi Jasa Pengiriman Barang belum berjalan dengan efektif karena terdapat beberapa variabel yang dianggap tidak signifikan.

\section{Saran}

Berdasarkan kesimpulan yang diambil dari hasil penelitian, maka saran untuk penelitian ini adalah sebagai berikut:

1. Meningkatkan kualitas sistem dan kualitas layanan, sehingga pemanfaatan sistem informasi untuk jasa pengiriman barang dapat optimal.

2. CV. Viradi Global Pratama sebaiknya mengadakan pendidikan dan pelatihan kepada para staff, khususnya staff yang berhubungan langsung atau menggunakan langsung Sistem Informasi Jasa Pengiriman Barang.

3. CV. Viradi Global Pratama sebaiknya melakukan penggantian atau upgrade peralatan hardware terutama spesifikasi server seperti memori, processor maupun media penyimpanannya dan upgrade software baik untuk sistem operasi maupun software aplikasi. Agar sistem dapat bekerja dengan baik.

4. Sebaiknya CV. Viradi Global Pratama melakukan pengecekan rutin infrastraktur jaringan yang ada.

5. Diharapkan juga kajian semacam ini dapat dilakukan secara periodik sehingga dapat dievaluasi keefektivitasan pemanfaatan sistem informasi untul pelayanan jasa pengiriman barang.

6. Penelitian dapat menggunakan model selain DeLone dan McLean, sehingga dapat diketahui faktor-faktor lain yang mempengaruhi efektivitas sistem informasi untuk pelayanan jasa pengiriman barang.

7. Penelitian dapat dilanjutkan dengan melakukan penataan variabel yang nantinya akan menjadi model yang diadopsi sebagai landasan dalam mengukur efektivitas pemanfaatan sistem informasi untuk pelayanan jasa pengiriman barang.

\section{Daftar Pustaka}

Bossen, C., Jensen, L. G., \& Udsen, F. W. (2013). Evaluation of a comprehensive EHR based on the DeLone and McLean model for IS success: Approach, results, and success factors. International Journal of Medical Informatics, 82(10), 940-953. http://doi.org/10.1016/j.ijmedinf.2013.05.010

Delone; McLean. (2003). DeLone and McLean IS Success Ten Year Update. Journal of Management Information Systems, 19, 9-30.

DeLone, W. H., \& Mclean, E. R. (2003). The DeLone and McLean Model of Information Systems Success: A Ten-Year Update. Journal of Management Information Systems / Spring, 19(4), 9-30. http://doi.org/10.1073/pnas.0914199107

Delone, W. H., \& Mclean, E. R. (2004). Measuring e-Commerce Success: Applying the DeLone \& McLean Information Systems Success Model. International Journal of Electronic Commerce, 9(1), 31-47. http://doi.org/1086-4415/2004

Hair, J. F., Ringle, C. M., \& Sarstedt, M. (2011). PLS-SEM: Indeed a Silver Bullet. The Journal of Marketing Theory and Practice, 19(2), 139-152. http://doi.org/10.2753/MTP1069- 
Jurnal String Vol.1 No.2 Tahun 2016

ISSN : $2527-9661$

6679190202

IBM SPSS Amos. (2012). IBM SPSS Amos. IBM Software Business Analytics, YTD03114-U, $1-8$.

Sutabri, Tata. (2004). Analisa Sistem Informasi. Yogyakarta: Penerbit Andi.

Tia Septiani. (2013). PENGERTIAN INFORMASI dan KOMUNIKASI. Retrieved from http://indonesiaindonesia.com/f/94325-pengertian-informasi-komunikasi/

Widowati, Endah. (2004). Pengukuran Konsep Efektifitas Sistem Informasi Penelitian Pendahuluan. Prosiding Seminar Nasional Aplikasi Teknologi Informasi. Yogyakarta: Universitas Gajah Mada.

http://journal.uii.ac.id/index.php/Snati/article/viewFile/1805/1584 